\title{
SEEDER PERFORMANCE UNDER DIFFERENT PRESSURES OF VACCUM AND FUEL CONSUMPTION TO SOYBEAN SEEDS
}

\author{
DEPOSIÇÃO DE SEMENTES DE SOJA EM DIFERENTES PRESSÕES DE \\ VÁCUO E CONSUMO DE COMBUSTÍVEL
}

\author{
Sidnei Marcelino LAURIANOㅜㅜ ; Saulo Fernando Gomes de SOUSA ${ }^{\mathbf{1}}$; Patrícia Pereira DIAS ${ }^{\mathbf{1}}$; \\ Tiago Pereira da Silva CORREIA ${ }^{2}$; Paulo Roberto Arbex SILVA ${ }^{1}$ \\ 1. Faculdade de Ciências Agronômicas, FCA - UNESP, Botucatu, SP, Brazil. eng.amb.patricia@gmail.com; 2. Faculdade de Agronomia \\ e Medicina Veterinária da Universidade de Brasília, FAV - UnB, Brasília, DF, Brazil.
}

\begin{abstract}
In pneumatic precision seeders, the regularity in seeds deposition is essential for a proper sowing process. Thus, the aim of this study was to verify the accuracy in the soy beans seed capturing in different vacuum pressures $(3.5 \mathrm{kPa} ; 4.0 \mathrm{kPa} ; 5.0 \mathrm{kPa} ; 5.5 \mathrm{kPa}$ and $6.0 \mathrm{kPa})$, the seed distribution in the seed lines as well as the fuel consumption in the tractor-seed set. The experiment was carried out at the College of Agronomy - FCA/UNESP, Botucatu-SP. The outline was random blocks, in subplots layout banded of $30 \times 3.15 \mathrm{~m}$, with four replicates per treatment. A tractor-seeder set was used to collect the sample of fuel consumption and seed population. The real population of seed was collected in plastic bags fastened to the end of the conductor pipe, obtaining the population of the 5 central lines of the seeders. The acquisition of the fuel consumption data for each plot, was carried out using a flow meter. Thus, it was observed that the seeder distribution on the vacuum pressure at 3.5; 4.0 and $5.5 \mathrm{kPa}$ decreased in the farthest lines when compared to the central lines. For the hourly fuel consumption, per area and also for the deposition of seeds the regularity in the distribution of seeds is affected when there is vacuum pressure below $5.0 \mathrm{kPa}$ and, consequently, highest consumption. For soybean sowing, seeds having the characteristics described in this study, it is recommended to use vacuum pressure of $6.0 \mathrm{kPa}$. As a result, this vacuum pressure leads to the lowest fuel consumption per hour, $11.49 \mathrm{~L} \mathrm{~h}^{-1}$ and worked area, $7.35 \mathrm{~L} \mathrm{ha}^{-1}$.
\end{abstract}

KEYWORDS: Plantability. Mechanization. Glycine max.

\section{INTRODUCTION}

The agricultural machinery and equipments, when are used properly, improves operational efficiency, allows the expansion of planted areas, provides increased yield and also allows complying the schedule of activities. However, such benefits may be annulled depending on the unsuitable use of the machines by the farmer.

For large extensions of crop area, it is essential the use of machines for depositing the seeds on the ground properly, providing an appropriate environment for the germination (KARAYEL; OZMERZI, 2007). Seed drill is defined by Machado et al. (2005), as being the agricultural machine that has the role to deposit all types of seeds on the ground, without mechanical damages, with recommended density, spacing and depth for the full development of the crop.

Sowing techniques and type of seeders play an important role in the deposition of seeds and seedling emergence which are directly associated to the plant growth and grain yield (KUMAR et al., 2013). Melo et al. (2013) evaluating precision seeders of horizontal and pneumatic disc, in two different operating speeds, concluded that the pneumatic seeder showed greater regularity in longitudinal seed distribution.

The seed metering mechanism in the pneumatic seeders has its own particular characteristics, such as peripheral speed of the disc and pressure of vacuum (ALONÇO et al., 2014). The pneumatic seed metering mechanism can provide a better distribution of seeds (TOURINO et al., 2009), less damage, better adjustment and better accuracy (ZHAN et al., 2010).

Li et al. (2012) highlighted the flexibility of the use with different types and sizes of seeds, with more precise dosing rates, less damage to the seed, better control and adaptation and a larger application spectrum. Oliveira et al. (2009), Jasper et al. (2011) and Melo et al. (2013) also identified best performance of these pneumatic seed metering mechanism in relation to mechanic metering.

The speed of displacement of the tractorseeder set is an important factor in the sowing operation (SILVEIRA et al., 2013). However, other factors can interfere in the accuracy of the sowing, Reis and Forcellini (2002) cite the regularity of distribution of seeds and seed metering errors. The accuracy of sowing depends directly on the accuracy in the seed metering mechanism performed 
by the meter of seed that, according to Dias (2009), is the most important organ of the seeder.

On the pneumatic meter, the selector position in the disc of seeds is another important item to the proper sowing, being the vacuum pressure of the meters the one that leads to suitable densities for each crops. The majority of studies with seeders equipped with these types of mechanisms focus on the speed of displacement, as in the works of Liu et al. (2004), Celik et al. (2007), Dias et al. (2009) and Jasper et al. (2011).

Thus, the aim of this study was to verify the accuracy of the soybean seed capturing, in the vacuum pressures $3.5 \mathrm{kPa} ; 4.0 \mathrm{kPa} ; 5.0 \mathrm{kPa} ; 5.5 \mathrm{kPa}$ and $6.0 \mathrm{kPa}$, the distribution of seeds by sowing lines and fuel consumption in a tractor-seeder set.

\section{MATERIAL AND METHODS}

The experiment was carried out in 2015 , at the College of Agronomy - FCA / UNESP, located in Botucatu-SP $\left(22^{\circ} 51^{\prime} \mathrm{S}\right.$ and $48^{\circ} 26^{\prime} \mathrm{W}$, average altitude of 770 meters).

The experimental outline was composed by blocks at random in subplots layout banded with four replicates per treatment. The treatments are composed by the evaluation of accuracy of the seed capturing according to the selector positions in the seed metering device, represented by $-5,-3,0,3$ and 5 , which are equivalent to the vacuum pressures represented by $3.5 \mathrm{kPa} ; 4.0 \mathrm{kPa}, 5.0 \mathrm{kPa}, 5.5 \mathrm{kPa}$ and $6.0 \mathrm{kPa}$ and distribution of seeds for sowing line (L1: line 1; L2: line 2; L3: line 3; L4: line 4 and L5: line 5). The variables seed population and fuel consumption were analyzed. The experimental area was $30 \mathrm{~m} \times 3.15\left(94.5 \mathrm{~m}^{2}\right)$ for each treatment.

A tractor-seeder set was carrying out the experiment, with New Holland tires, model TS 110, $4 \times 2$ FWA (front wheel assist), with engine rated power of $80.5 \mathrm{~kW}(109.5 \mathrm{hp})$, and a seeder precision Jumil, model Exacta 2980 PD, with seven seeding lines, helicoidal fertilizer, and pneumatic system for seeding deposition, with seed discs Jumil 7045 (diameter $247 \mathrm{~mm}$, thickness $1 \mathrm{~mm}$, number of holes 75 , hole diameter $5 \mathrm{~mm}, 4.5 \mathrm{~mm}$ distance between holes), spaced at $0.45 \mathrm{~m}$, totaling $2.25 \mathrm{~m}$ wide.

The soybean seeds were characterized by the weight of a thousand seeds and sphericity, that it was determined by the equation described by Karayel et al. (2004):

$$
\emptyset=\frac{(\mathrm{L} . \mathrm{W} \cdot \mathrm{T})^{1 / 3}}{\mathrm{~L}} \times 100
$$

Where: $\varnothing$ is the sphericity (\%); L, W and T refers to the length, width and thickness of the seed $(\mathrm{mm})$, respectively.
The soybean seed dimensions were determined with the aid of a pachymeter with accuracy of $0.05 \mathrm{~mm}$, in 50 seeds, with length of 6.7 $\mathrm{mm}$, width of $5.8 \mathrm{~mm}$, thickness of $5.5 \mathrm{~mm}$, sphericity of $89.1 \mathrm{~mm}$ and weight of $159 \mathrm{~g}$ for thousand seeds. EMBRAPA (1991) describes that one of the factors which affects the distribution of the seeds is the uniformity of seed width.

The tractor-seeder set was driven at $5 \mathrm{~km}$ $\mathrm{h}^{-1}$, with an approximate rotation in a $1900 \mathrm{rpm}$ engine, without front wheel assist, on solid ground with steepness lower than $5 \%$, with a theoretical population of 266,600 seeds ha ${ }^{-1}\left(12\right.$ seeds $\left.\mathrm{m}^{-1}\right)$.

The real population of seeds was collected in plastic bags fastened to the end of the conductor pipe, obtaining the populations of the 5 central lines of the seeder, and after this procedure the number of the seeds were measured by hand, adjusting the number to seeds per hectare.

The acquisition of fuel consumption data for each plot was carried out using a flow meter "oval Flowmate" Oval M-III model, accurate to $0.01 \mathrm{~mL}$. The flow meter was installed close to the tractor fuel filter, registering one pulse unit for each $\mathrm{ml}$ of fuel which passes by it.

The hourly fuel consumption and fuel consumption by worked area the following were calculated by the ensuing formulas:

$$
\mathrm{Ch}=3,6: \frac{\mathrm{Cc}}{\mathrm{Tp}}
$$

Where: $\mathrm{Ch}$ is hourly fuel consumption $\mathrm{L} \mathrm{h}^{-1}$; $\mathrm{Cc}$ is fuel consumption per plot; $\mathrm{Tp}$ is time spent per plot; 3.6 is a correction factor.

$$
\text { Cha }=\mathrm{Ch} * \frac{\mathrm{T}}{\mathrm{ha}}
$$

Where: Cha is fuel consumption by worked area $\mathrm{L} \mathrm{ha}^{-1}$; Ch is fuel hourly consumption $\mathrm{L} \mathrm{h}^{-1}$; $\mathrm{T}$ $\mathrm{ha}^{-1}$ is time spent per hectare.

The results were submitted to analysis of variance at $5 \%$ probability by the $\mathrm{F}$ test, the means were compared by Tukey test at 5\% significance, with the statistical program SISVAR (FERREIRA, 2011). After analysis of variance quantitative treatments were submitted to regression analysis, with the statistical program SigmaPlot 11.0.

\section{RESULTS AND DISCUSSION}

The soybean plantability is affected when the vacuum pressure is below $5.0 \mathrm{kPa}$, for the hourly fuel consumption, worked area and seed deposition it is verified that, as shown in Table1. 
Table 1. Averages of the parameters of fuel consumption and seeds deposition, depending on the different vacuum pressures.

\begin{tabular}{llll}
\hline $\begin{array}{l}\text { Vacuum Pressures } \\
(\mathrm{kPa})\end{array}$ & $\begin{array}{l}\text { Fuel consumption } \\
\text { Hourly } \\
\left(\mathrm{L} \mathrm{h}^{-1}\right)\end{array}$ & $\begin{array}{l}\text { Worked area } \\
\left(\mathrm{L} \mathrm{ha}^{-1}\right)\end{array}$ & $\begin{array}{l}\text { Seeds deposition } \\
(\mathrm{ha})\end{array}$ \\
\hline 3.5 & $11.56 \mathrm{~B}$ & $7.39 \mathrm{~B}$ & $90221 \mathrm{~B}$ \\
4.0 & $12.35 \mathrm{~A}$ & $7.90 \mathrm{~A}$ & $139808 \mathrm{~B}$ \\
5.0 & $11.93 \mathrm{AB}$ & $7.63 \mathrm{AB}$ & $207744 \mathrm{~A}$ \\
5.5 & $11.63 \mathrm{~B}$ & $7.44 \mathrm{~B}$ & $230696 \mathrm{~A}$ \\
6.0 & $11.49 \mathrm{~B}$ & $7.35 \mathrm{~B}$ & $233902 \mathrm{~A}$ \\
\hline & & ANOVA & 62575 \\
\hline LSD & 0.65 & 0.41 & 15.38 \\
$\mathrm{C} . \mathrm{V} .(\%)$ & 2.46 & 2.46 & $20.67 * *$ \\
$\mathrm{~F}$ & $5.94 * *$ & $5.94 * *$ & \\
\hline
\end{tabular}

Means followed by the same letter in the columns do not differ from each other by Tukey test at 5\% probability. LSD: Least significant difference. C.V.: Coefficient of variation in \%. F: Test statistic F ** Significant at the $1 \%$ of probability.

Sowing with adjustment of the vacuum pressure $6.0 \mathrm{kPa}$ in the seed metering device, were deposited more adequately population, it is observed the statistical similarity with pressures of 5.5 and 5.0 $\mathrm{kPa}$. For the fuel consumption has the lowest consumptions to 5.5 and $6.0 \mathrm{kPa}$ vacuum pressure.

In a seeder the selector position and the seed metering device allows only one adjustment of vacuum pressure, with the adaptation of suction to the seed weight (JUMIL, 2010). From this information is appropriate, based on the data of Table 1 , to choice the selector position in 3 or 5 , which corresponds in 5.5 and $6.0 \mathrm{kPa}$.

Francetto et al. (2015) describe that the sizing of the seeder can decrease the production cost due to the reduced number of interruptions for fuel supply and Machado et al. (2015) evaluating variable rate in seeders described that the causes of poor performance is attributed to effects such as equipment calibration.

The distribution of seeds per set was also covered in this study, with the seeds being collected in 5 lines of the seeder. The results are shown as polynomial regression in Figure 1.

Based on the regression analysis, it is possible to conclude that the seed distribution in the vacuum pressures $3.5 ; 4.0$ and $5.5 \mathrm{kPa}$ (Figure $1 \mathrm{~A}$, $\mathrm{B}$ and D) decrease the farthest lines when related to the center line of the seeder, which is where the engine responsible by the vacuum is located. However, in the pressure $5.5 \mathrm{kPa}$ there is a significant quadratic effect, but with less accuracy for lines 1 and 5 due to the standard error, which makes it similar to 5.0 and $6.0 \mathrm{kPa}$ pressure. As already described in Table 1, the highest vacuum pressures lead to better distribution of soybean seeds.

Tourino et al. (2007) reported that in the seed metering pneumatic the negative pressure can influence in the capturing of the seeds. To define the variation in the distribution of seeds (Table 2) as acceptable $<10 \%$ or not $>10 \%$ among the lines of the same seeder, the methodology proposed by Weirich Neto et al. (2015) was adopted, calculating by the percentage among the number of seeds by lines, was obtained through the difference between the highest and lowest number of seeds divided by the lowest number of seeds.

Pointing out the data previously indicated in this study, there was lowest variations for the largest vacuum pressures. Considering the average population of 233,902 seeds $\mathrm{ha}^{-1}$ and variation of $0.21 \%$, these are the data that come closest to the intended for sowing, highlighting the vacuum pressure $6.0 \mathrm{kPa}$. Schimandeiro et al. (2006) also found variations among the sowing lines, with larger populations to the center lines. Weirich Neto et al. (2015) evaluating 64 seeders in five crops, point out the variation over $10 \%$ among the lines of the same seeder, which could bring loss to the productivity. 

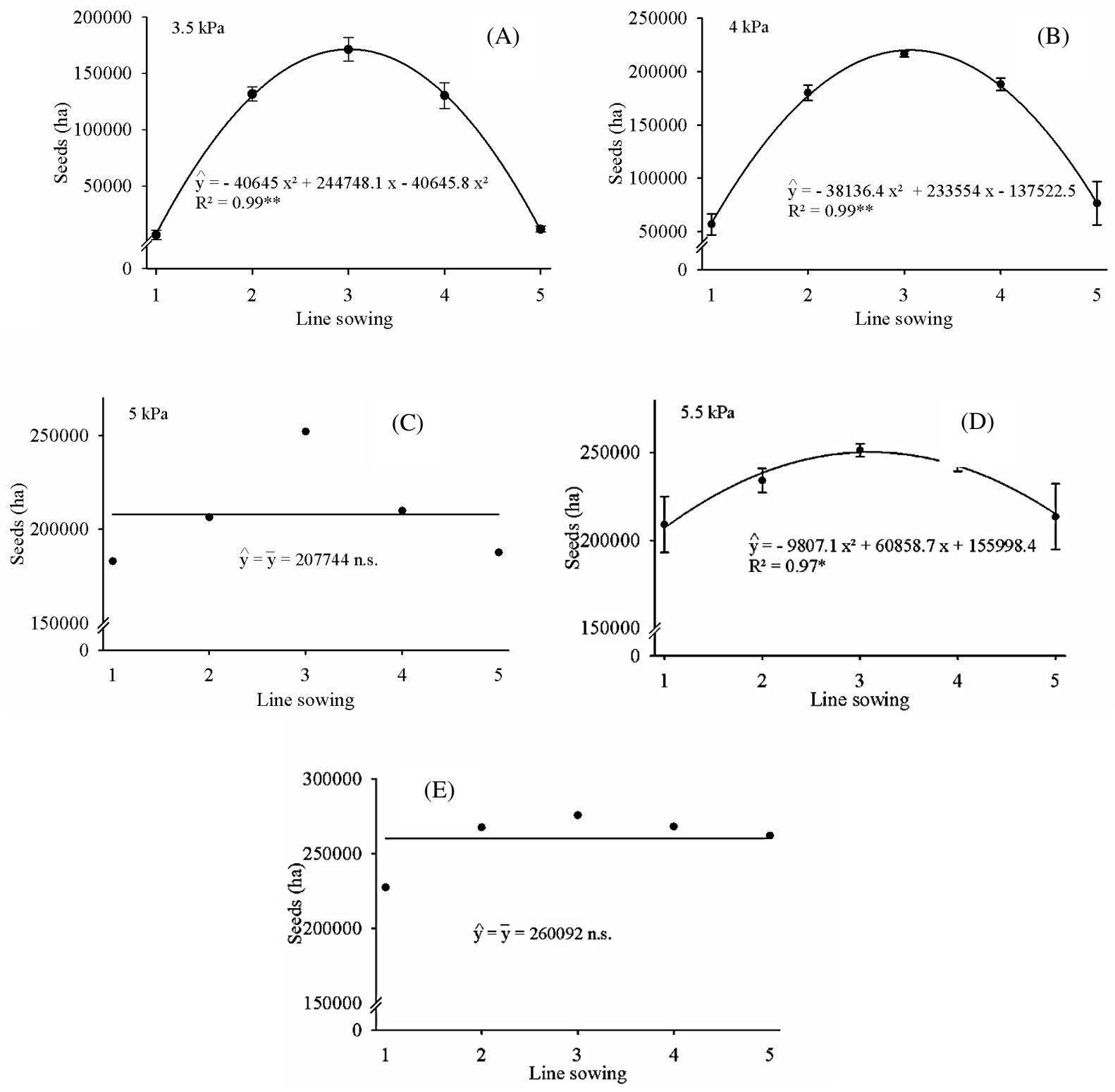

Figure 1. Distribution of the number of seeds $\left(\mathrm{ha}^{-1}\right)$ by sowing line for the different vacuum pressures $(\mathrm{A}-3.5$; $\mathrm{B}-4.0 ; \mathrm{C}-5.0 ; \mathrm{D}-5.5$ and $\mathrm{E}-6.0 \mathrm{kPa}$ ). Vertical bars indicate the mean \pm standard error of the mean. n.s.: not significant at $5 \%$ probability. ${ }^{* *},{ }^{*}$ Significant at 1 and $5 \%$ probability, consecutively.

Table 2. Variation in the distribution of seeds between the lines of the seeder.

\begin{tabular}{llll}
\hline $\begin{array}{l}\text { Vacuum Pressure } \\
(\mathrm{kPa})\end{array}$ & $\begin{array}{c}\text { Seeds deposited }\left(\mathrm{ha}^{-1}\right) \\
\text { Maximum }\end{array}$ & Minimum & $\begin{array}{l}\text { Variation } \\
\%\end{array}$ \\
\hline 3.5 & 171268.15 & 6349.14 & 25.97 \\
4.0 & 216505.75 & 56983.56 & 2.79 \\
5.0 & 252060.97 & 182855.31 & 0.37 \\
5.5 & 251426.05 & 209045.52 & 0.20 \\
6.0 & 275711.50 & 227299.30 & 0.21 \\
\hline
\end{tabular}




\section{CONCLUSIONS}

The vacuum pressure of $6.0 \mathrm{kPa}$ is recommended for soybean sowing, when the seeds have sphericity of $89.1 \mathrm{~mm}$ and weight of thousand seeds of $159 \mathrm{~g}$. As a result, this vacuum pressure leads to the lowest fuel consumption per hour, 11.49 $\mathrm{L} \mathrm{h}^{-1}$ and worked area, 7.35 $\mathrm{L} \mathrm{ha}^{-1}$.

The adjustment and inspection line by line of the seeder it is essential for less variation among the sowing lines, thus achieving better results. For seeds of lower weight it is required higher vacuum pressure.

RESUMO: Nas semeadoras de precisão pneumáticas a regularidade na deposição de sementes é primordial para uma correta semeadura. Assim, o objetivo deste estudo foi verificar a acurácia na captura de sementes de soja em diferentes pressões de vácuo $(3,5 \mathrm{kPa} ; 4 \mathrm{kPa} ; 5 \mathrm{kPa} ; 5,5 \mathrm{kPa}$ e $6 \mathrm{kPa})$, a distribuição das sementes nas linhas da semeadora e, também, verificar o consumo de combustível do conjunto trator-semeadora. Realizou-se o experimento na Faculdade de Ciências Agronômicas - FCA/UNESP, Botucatu-SP. O delineamento experimental foi de blocos ao acaso, em esquema de subparcelas (faixas de $30 \times 3,15 \mathrm{~m}$ ), com quatro repetições por tratamento. Um conjunto trator-semeadora foi utilizado coletando-se as amostras de consumo de combustível e população de sementes. Sendo as sementes coletadas em sacos plásticos fixados ao final do tubo condutor, obtendo as populações das 5 linhas centrais da semeadora. A obtenção dos dados de consumo de combustível para cada parcela foi realizada utilizando-se um fluxômetro. Assim verificou-se que a distribuição de sementes nas pressões de vácuo 3,5; 4 e 5,5 $\mathrm{kPa}$ decrescem nas linhas mais distantes do centro da semeadora. Para o consumo de combustível horário, por área e deposição de sementes verifica-se que a regularidade na distribuição de sementes é afetada quando se tem pressões de vácuo abaixo de $5 \mathrm{kPa}$ e, consequentemente, maiores consumos. Para semeadura de soja, com as características das sementes como neste trabalho, é recomendando utilizar a pressão de vácuo de $6 \mathrm{kPa}$. Apresentando esta pressão de vácuo menor consumo de combustível por hora, 11,49 L h ${ }^{-1} \mathrm{e}$ área trabalhada, 7,35 $\mathrm{L} \mathrm{ha}^{-1}$.

PALAVRAS-CHAVE: Plantabilidade. Mecanização. Glycine max.

\section{REFERENCES}

ALONÇO, A. S.; SILVEIRA, H. A. T.; BELLÉ, M. P.; MACHADO, O. D. C.; FRANCETTO, R. T. Efeito da inclinação transversal sobre o desempenho de dosadores pneumáticos em diferentes velocidades de operação. Revista Energia na Agricultura, Botucatu, v. 29, n. 3, p. 174-181, 2014.

CELIK, A.; OZTURK, I; WAY, T. R. Effects of Various Planters on Emergence and Seed Distribution Uniformity of Sunflower. American Society Of Agricultural And Biological Engineers. Maryland, Jan. 2007. p. 57-61. Disponível em: <http://handle.nal.usda.gov/10113/19264>. Acesso em: 26 jan. 2015.

DIAS, V. O. Desempenho de dois protótipos de semeadoras-adubadoras para plantio direto. 2009. $80 \mathrm{f}$. Dissertação (Mestrado) - Curso de Engenharia Agrícola, Universidade Federal de Santa Maria, Santa Maria, 2009.

DIAS, V. O.; ALONÇO, A. S.; BAUMHARDDT, U. B.; BONOTTO, G. J. Distribuição de sementes de milho e soja em função da velocidade e densidade de semeadura. Ciência Rural, Santa Maria, v. 39, p. 1721-1728, 2009. https://doi.org/10.1590/S0103-84782009005000105

EMPRESA BRASILEIRA DE PESQUISA AGROPECUÁRIA. COMUNICADO TÉCNICO 48:

Uniformidade de distribuição de plantas em lavouras de soja. Londrina: Embrapa, 1991. 9 p.

FERREIRA, D. F. Sisvar: a computer statistical analysis system. Ciência e Agrotecnologia, Lavras, v. 35, n. 6, p. 1039-1042, Nov./Dec., 2011.

FRANCETTO, T. R.; DAGIOS, R. F.; LEINDECKER, J. A.; ALONÇO, A. S.; FERREIRA, M. F. Características dimensionais e ponderais das semeadoras-adubadoras de precisão no Brasil. Tecno-Lógica, Santa Cruz do Sul, v. 19, n. 1, p.18-24, abr. 2015. 
JASPER, R.; JASPER, M.; ASUMPÇÃO, P. S. M.; ROCIL, J.; GARCIA, L. C. Velocidade de semeadura da soja. Engenharia Agrícola, Jaboticabal, v. 31, p. 102-110, 2011.

JUSTINO DE MORAIS IRMÃOS S/A. Manual de instruções JM 2980 PD Pivotada. Batatais: Jumil, 2010. $176 \mathrm{p}$.

KARAYEL, D.; BARUT, Z. B.; ÖZMERZI, A. Mathematical modelling of vacum pressure on a precision seeder. Biosystems Engineering, London, v. 87, n. 4, p. 437-444, 2004.

https://doi.org/10.1016/j.biosystemseng.2004.01.011

KARAYEL, D.; ÖZMERZI, A. Comparison of vertical and lateral seed distribution of furrow openers using a new criterion. Soil and Tillage Research, Amsterdam, v. 95, p. 69-75, 2007.

https://doi.org/10.1016/j.still.2006.11.001

KUMAR, S.; SINGH, M.; SINGH, B. R. Feasibility and economic viability of raised bed planter in western plane zone of Uttar Pradesh, India. Soil and Tillage Research, Amsterdam, v. 128, p. 37-43, 2013. https://doi.org/10.1016/j.still.2012.10.008

LI, X.; LIAO, Q.; YU, J.; SHU, C.; LIAO, Y. Dynamic analysis and simulation on sucking process of pneumatic precision metering device for rapeseed. Journal of Food, Agriculture \& Environment, Helsinki, v. 10, n. 1, p. 450-454, 2012.

LIU, W.; TOLLENAAR, M.; STEWART, G.; DEEM, W. Impact of planter type, planting speed, and tillage on stand uniformity and yield of corn. Agronomy Journal, Madison, v. 96, n. 6, p. 1668-1672, 2004.

https://doi.org/10.2134/agronj2004.1668

MACHADO, A. L. T.; REIS, A. V.; ALONÇO, A. S. Máquinas para Semeadura e Adubação. In: Máquinas para preparo do solo, semeadura, adubação e tratamentos culturais. 2. ed. Pelotas: Universitária Ufpel, 2005. p. 101-190.

MACHADO, O. D. C.; ALONÇO, A. S.; BELLÉ, M. P.; FRANCK, C. J. Acurácia das semeadoras-adubadoras à taxa variável. Ciencia Rural, Santa Maria, v. 45, n. 7, p. 1205-1213, jul. 2015. https://doi.org/10.1590/01038478 cr20141397

MATTAR, D. M. P. Influência do deslizamento da roda motora de uma semeadora/adubadora de plantio direto no espaçamento longitudinal de sementes de milho. 2010. 67 f. Dissertação (Mestrado) - Curso de Engenharia Agrícola, Universidade Federal de Santa Maria, Santa Maria, 2010.

MELO, R. P.; ALBIERO, D.; MONTEIRO, L. A.; SOUZA, F. H.; SILVA, J. G. Qualidade na distribuição de sementes de milho em semeadoras em um solo cearense. Revista Ciência Agronômica, Fortaleza, v. 44, n. 1, p. 94-101, 2013. https://doi.org/10.1590/S1806-66902013000100012

OLIVEIRA, L. G.; TAVARES, C. A.; GRIGGIO, A.; DELAI, M.; JUNG, R.; BITENCOURT, R.; SILVA, S. L.; SILVA, T. R. B. Distribuição longitudinal de sementes de milho em função do tipo de dosador de sementes e velocidade de deslocamento. Cultivando o Saber, Cascavel, v. 2, n. 1, p. 140-146, 2009.

REIS, A. V.; FORCELLINI, F. A. Análise da precisão funcional da semeadora. 2002. Disponível em: <http://wp.ufpel.edu.br/nimeq/files/2011/04/Tecno-Lógica-v-6-n2-p-91-104.pdf>. Acesso em: 26 jan. 2015.

SCHIMANDEIRO, A.; WEIRICH NETO, P. H.; GIMENEZ, L. M.; COLET, M. J.; GARBUIO, P. W. Distribuição longitudinal de plantas de milho (Zea mays L.) na região dos Campos Gerais, Paraná. Ciência Rural, Santa Maria, v. 36, n. 3, p. 977-980, 2006. https://doi.org/10.1590/S0103-84782006000300040 
SILVEIRA, J. C. M.; HAROLDO, C. F.; MODOLO, A. J.; SILVA, S. L.; TROJELLO, E. Demanda energética de uma semeadora-adubadora em diferentes velocidades de deslocamento e rotações do motor. Revista Ciência Agronômica, Fortaleza, v. 44, n. 1, p. 44-52, 2013. https://doi.org/10.1590/S1806-66902013000100006

TOURINO, M. C. C.; REZENDE, P.M.; SILVA, L. A.; ALMEIDA, L. G. P. Semeadoras-adubadoras em semeadura convencional de soja. Ciência Rural, Santa Maria, v. 39, n. 1, p. 241-245, 2009.

https://doi.org/10.1590/S0103-84782009000100039

TOURINO, M. C. C.; SILVA, P. M. R.; ALMEIDA, L. G. P.; SILVA, L. A. Comparativo na uniformidade / distribuição de sementes em função dos tipos de semeadoras. Revista Brasileira Agrociência, Pelotas, v. 13, n. 3, p. 383-392, 2007.

WEIRICH NETO, P. H.; FORNARI, A. J.; JUSTINO, A.; GARCIA, L. C. Qualidade na semeadura do milho. Engenharia Agrícola, Jaboticabal, v. 35, n. 1, p. 171-179, 2015.

ZHAN, Z.; YAOMING, L.; JIN, C.; LIZHANG, X. Numerical analysis and laboratory testing of seed spacing uniformity performance for vacuum-cylinder precision seeder. Biosystems Engineering, London, v. 106, n. 4, p. 344-351, 2010. https://doi.org/10.1016/j.biosystemseng.2010.02.012 